PENENTUAN NASABAH PENERIMA REWARD PRODUK GOLD DENGAN METODE SIMPLE ADDITIVE WEIGHTING (SAW) STUDI KASUS : PT. PINJAM INDONESIA

Riki Ruli A. Siregar; Faizal Fachrurrozi

IMPLEMENTASI METODE BACKWARD CHAINING PADA DATA WAREHOUSE DAOP 1 JAKARTA PT. KAI (PERSERO) Rakhmat Arianto; Chandra Bagus Sugiarto

IMPLEMENTASI METODE DETEKSI TEPI CANNY PADA OBJEK SEBAGAI MODEL KEAMANAN APLIKASI PADA SMARTPHONE ANDROID

Abdul Haris; Andi Prasetyo

ANALISA DATA DAN PERANCANGAN APLIKASI SERVICE PELANGGAN PT. JNE UNTUK PENINGKATAN KUALITAS LAYANAN

Dewi Arianti Wulandari; Sonny Syahrindra Putra

JARINGAN AD-HOC VEHICULAR (VANET) : TINJAUAN TENTANG ARSITEKTUR, KARAKTERISTIK, APLIKASI, DAN PROTOKOL MEDIUMACCESS CONTROL (MAC)

Rosida Nur Aziza

PERANCANGAN APLIKASI PENJADWALAN MATA KULIAH MENGGUNAKAN METODE CONSTRAINT PROGRAMMING Syam Gunawan

RANCANGAN TATA KELOLA PEREMAJAAN RUANG KELAS DIREKTORAT PEMBINAAN SEKOLAH DASAR

Ratna Mutu Manikam; Purwanto

PENGEMBANGAN AMORIK MENGGUNAKAN METODE GARIS SINGGUNG TERHADAP DUA LINGKARAN DAN PERSAMAAN KURVA BEZIER ORDE DUA.

Darma Rusjidi

OPTIMALISASI PENGAMBILAN KEPUTUSAN PENILAIAN KINERJA DOSEN PADA PERGURUAN TINGGI ISLAM XYZ MENGGUNAKAN AHP (ANALYTICAL HIERARCHY PROCESS)

Rahma Farah Ningrum

PENGAMANAN SMS PADA TELEPON SELULER BERBASIS ANDROID MENGGUNAKAN ALGORITMA TRIPLE DES Raka Yusuf; $M$. Rival Suheri

APLIKASI LATIHAN SOAL UJIAN TEORI SURAT IZIN MENGEMUDI BERBASIS WEB Harni Kusniyati; Raka Yusuf; Andri Setiawan

RANCANG BANGUN SIMULASI TERJADINYA LISTRIK DENGAN SUMBER DAYA SAMPAH BERBASIS MULTIMEDIA (STUDI KASUS : TPST BANTAR GEBANG)

Yasni Djamain; Ika Fitriyani Putri

\begin{tabular}{|c|c|c|c|c|c|c|}
\hline \multirow{2}{*}{ 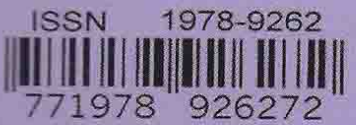 } & \multicolumn{6}{|c|}{ SEKOLAH TINGGI TEKNIK - PLN (STT-PLN) } \\
\hline & PETIR & VOL. 9 & No. 1 & HAL. 1 - 87 & JAKARTA, MARET 2016 & ISSN $1978-9262$ \\
\hline
\end{tabular}




\title{
ANALISA DATA DAN PERANCANGAN APLIKASI SERVICE PELANGGAN PT.JNE UNTUK PENINGKATAN KUALITAS LAYANAN
}

\author{
Dewi Arianti Wulandari; Sonny Syahrindra Putra \\ Program Studi Teknik Informatika Sekolah Tinggi Teknik PLN Jakarta \\ dewi_ardari03@yahoo.com; sonnysp@yahoo.com
}

\begin{abstract}
Pelayanan merupakan faktor yang amat penting khususnya bagi perusahaan yang bergerak dibidang jasa. Pelayanan pelanggan ini sangat penting artinya bagi kehidupan suatu perusahaan, karena tanpa pelanggan, maka tidak akan terjadi transaksi jual beli diantara keduanya. Untuk itu kegiatan pelayanan perusahaan haruslah berorientasi pada kepuasan pelanggan.

Kualitas pelayanan diberikan kepada konsumen harus berfungsi untuk lebih memberikan kepuasan yang maksimal, oleh karena itu dalam rangka memberikan pelayanan harus dilakukan sesuai dengan fungsi pelayanan. Kualitas pelayanan yang diberikan oleh setiap perusahaan tentunya mempunyai tujuan. Umumnya tujuan dengan diadakannya pelayanan adalah agar konsumen merasakan adanya kepuasan dan dampaknya bagi perusahaan akan memperoleh laba maksimum.

Aplikasi dengan menggunakan metode K-Means diharapakan pola data yang dihasilkan dapat memberikan gambaran tentang kualitas pelayanan. Pola data berdasarkan tahun dan service akan terlihat dalam tiga cluster
\end{abstract}

Kata Kunci : K-means, Pelayanan, Kualitas, Aplikasi,

\section{PENDAHULUAN}

\section{A. Latar Belakang}

Kepuasaan pelanggan adalah reaksi atau umpan balik yang diberikan para konsumen setelah terpenuhinya kebutuhan mereka akan sebuah produk ataupun jasa. Dengan demikian konsumen memperoleh rasa nyaman dan senang karena harapannya telah terpenuhi. Selain itu kepuasan pelanggan juga sering dijadikan sebagai salah satu tujuan utama dari strategi pemasaran bisnis, baik bisnis yang dijalankan dengan memproduksi barang maupun bisnis jasa.

Keberhasilan strategi pemasaran suatu usaha dapat dicapai jika kepuasan pelanggan telah terpenuhi. Namun untuk memperoleh kepuasan pelanggan tidaklah mudah, karena tiap pelanggan memiliki tingkat kepuasan yang berbeda-beda walaupun membutuhkan produk yang sama. Proses pemenuhan kepuasan pelanggan tidak hanya membutuhkan produk atau jasa yang berkualitas saja, namun juga membutuhkan adanya sistem pelayanan yang mendukung. Sehingga para pelanggan akan merasa senang dengan produk atau jasa yang dibutuhkan, serta nyaman dengan pelayanan yang diberikan.

Salah satu contoh perusahaan swasta yang bergerak dibidang penjualan jasa adalah PT JNE (Tiki Jalur Nugraha Ekakurir), adapun penjualan jasanya adalah dalam bidang penjualan jasa pengiriman ke seluruh daerah di Indonesia. Jenis pelayanan yang ada terbagi menjadi Yakin Esok Sampai (YES), Regular (REG) dan Ongkos Kirim Ekonomis (OKE). Pada data pengiriman cabang JNE Cimone Tangerang didapatkan service REG (Regular) selama tiga tahun berjumlah 589760 dan rata rata 49146,67, service YES (Yakin Esok Sampai) berjumlah 109169 dan rata-rata 9097.417, service OKE (Ongkos Kirim Ekonomis) berjumlah 145002 dan rata-rata 12083,5 .

Berdasarkan uraian singkat di atas dapat dijadikan penelitian dengan tema bagaimana meningkatkan kualitas pelayanan pengiriman pada JNE dengan menggunakan metode K-Means.

\section{B. Batasan Masalah}

Batasan masalah berdasarkan latar belakang diatas sebagai berikut :

1. Data yang digunakan untuk clustering merupakan data service pelanggan REG (Regular), YES (Yakin Esok Sampai), dan OKE (Ongkos Kirim Ekonomis) pada JNE Cimone Tangerang selama tiga tahun mulai dari tahun 2012 hinggan tahun 2014.

2. Pengclusteran berdasarkan service pengiriman yaitu YES (Yakin esok sampai), REG (Regular), OKE (Ongkos kirim ekonomis).

C. Rumusan Masalah

Rumusan masalah pada penelitian ini adalah sebagai berikut :

1. Apakah metode K-Means dapat meningkatkan kualitas pelayanan bagi pelanggan PT. JNE ?

2. Bagaimana pola klasifikasi data service pelanggan PT. JNE menggunakan metode $K$ means?

D. Tujuan pada penelitian ini sebagai berikut:

1. Mengetahui pola sebaran data service pelanggan tiap tahunnya.

2. Meramalkan target service pelanggan untuk tahun berikutnya.

3. Dapat meningkatkan kualitas pelayanan pada pelanggan 
E. Manfaat dari penelitian ini sebagai berikut:

1. Mengetahui pola data service pelanggan tiap tahunnya.

2. Membantu bagian cash counter klasifikasi data service pelanggan.

3. Meningkatkan pelayanan berdasarkan data service pelanggan.

4. Dapat meningkatkan jumlah pelanggan.

\section{LANDASAN TEORI}

\section{A. Data mining}

Data mining merupakan suatu istilah yang digunakan untuk menemukan pengetahuan yang tersembunyi di dalam database. Data mining merupakan proses semi otomoatik yang menggunakan teknik statistic, matematika, kecerdasan buatan dan machine learning untuk mengekstraksi dan mengidentifikasi informasi pengetahuan potensial dan berguna yang bermanfaat yang tersimpan di dalam database besar. Data mining adalah suatu proses menemukan hubungan yang berarti,pola dan kecendrungan dengan memeriksa dalam sekumpulan besar data yang tersimpan dalam penyimpanan dengan menggunakan teknik pengenalan pola seperti teknik statistik dan matematika.

Proses KDD (Knowledge Discovery in Database) secara garis besar dapat dijelaskan sebagai berikut :

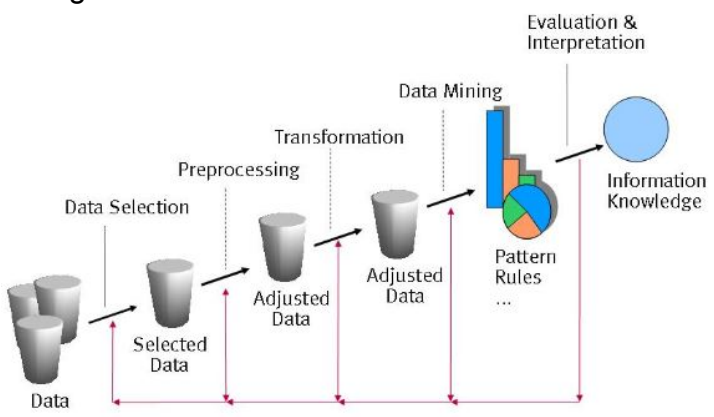

Gambar 2.1. Proses Data mining

\section{B. K-Means}

Algoritma $\mathrm{K}$-Means pertama kali diperkenalkan oleh J. MacQueen pada tahun 1967 melalui papernya yang merupakan suatu metode penganalisaan data atau metode data mining yang melakukan proses pemodelan tanpa supervisi dan merupakan salah satu metode yang melakukan pengelompokkan data yang ada ke dalam beberapa kelompok, dimana data dalam satu kelompok mempunyai karakteristik yang berbeda dengan data yang ada di dalam kelompok yang lain. Metode ini berusaha untuk meminimalkan variasi antar data yang ada di dalam suatu cluster dan memaksimalkan variasi dengan data yang ada di cluster lainnya. (Agusta,2007)
Algoritma $K$-Means untuk menghasilkan $K-$ Cluster:

1. Pilih k buah data/pattern secara acak untuk mereprresentasikan $\mathrm{k}$ inisial centroid.

2. Masukkan setiap data/pattern ke centroid yang terdekat.

3. Menghitung centroid baru dari suatu kelompok dengan menggunakan anggota kelompok saat ini.

4. Ulangi langkah 2 dan 3 sampai posisi centroid baru dan centroid lama tidak sama.

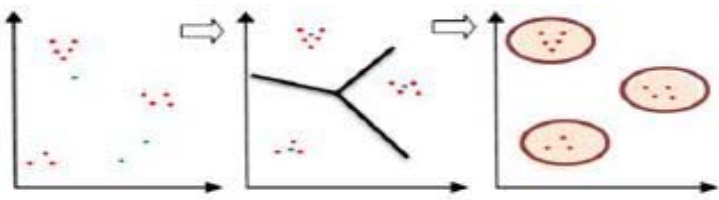

Gambar 2.2. Ilustrasi Algoritma K-Means

\section{METODOLOGI PENELITIAN}

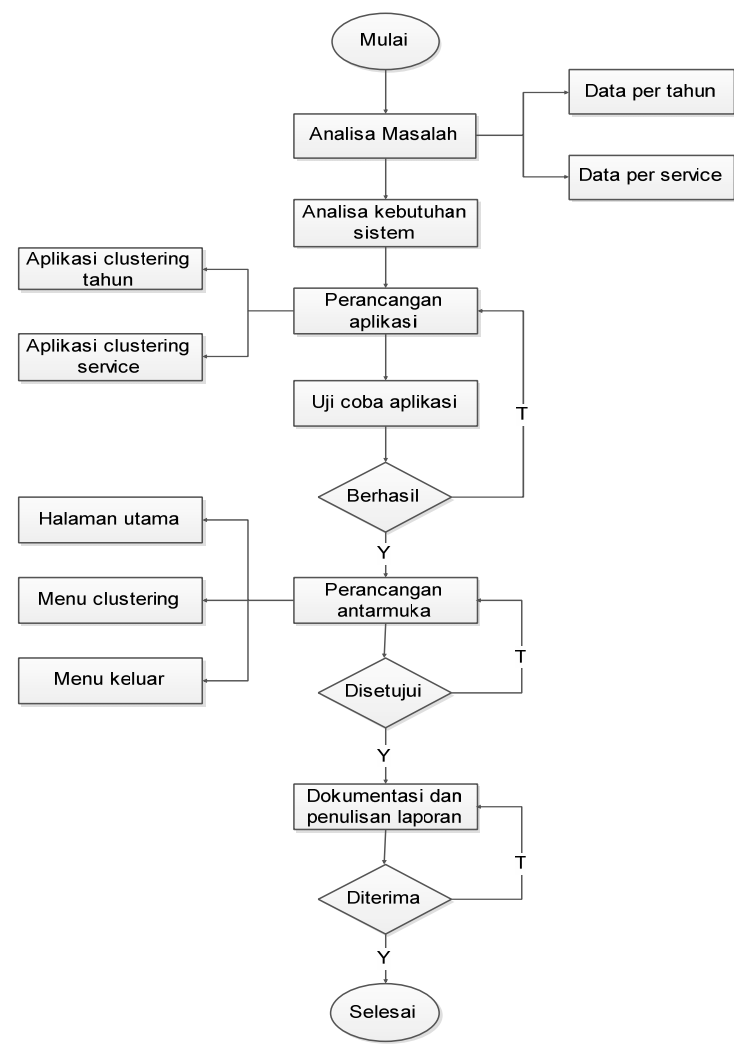

Gambar 3.1. Kerangka Penelitian

\subsubsection{Analisa Sistem Yang Diusulkan}

Sistem baru yang diusulkan diharapkan dapat mengatasi masalah yang ada pada sistem lama. Pihak perusahaan diharapkan dapat mengetahui pola pengelompokkan data service pelanggan untuk menentukan target selanjutnya. 


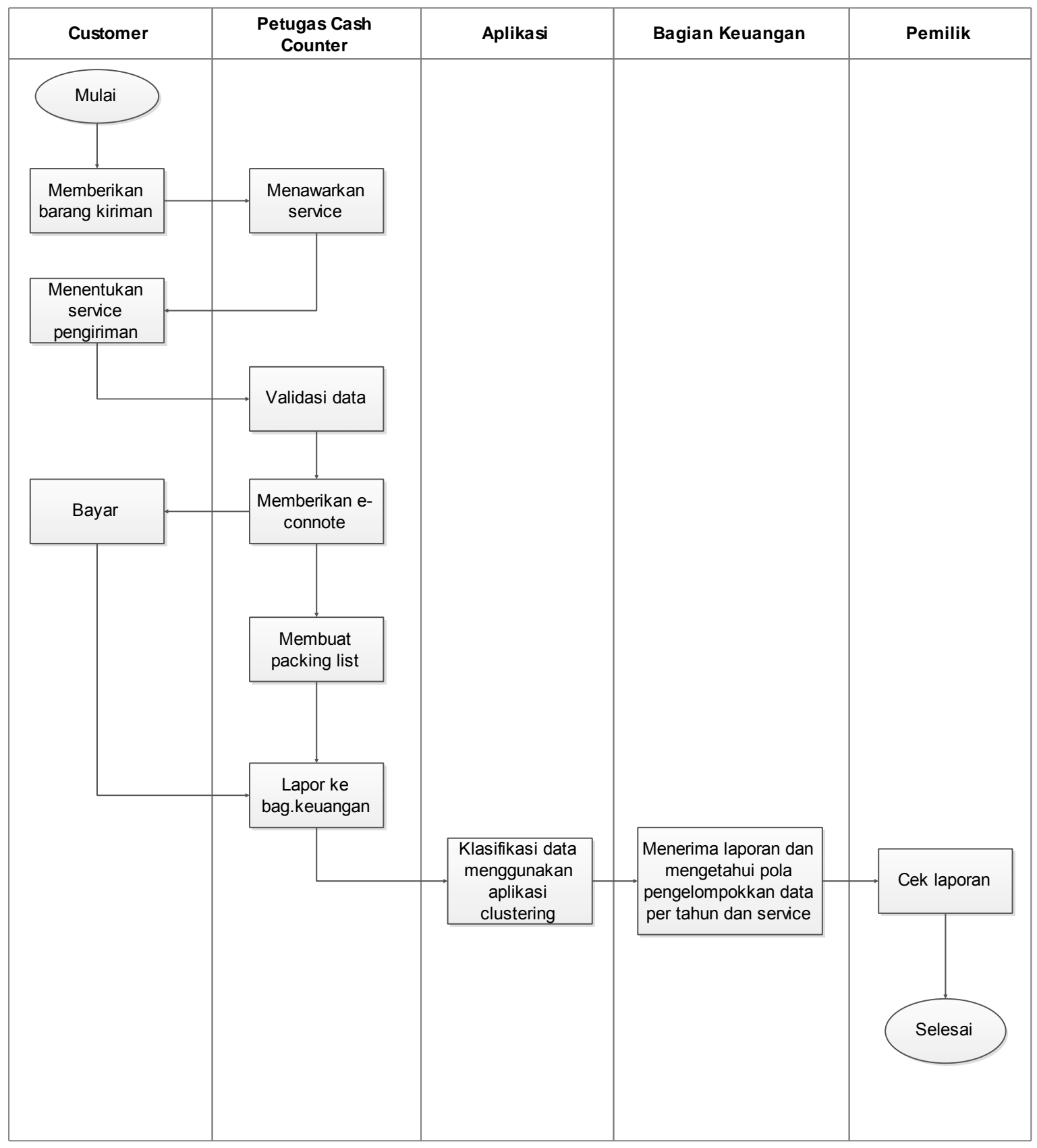

Keterangan Flow Diagram di atas sebagai berikut :

1. Customer memberikan barang kirimannya pada petugas cash counter.

2. Petugas Cash Counter menerima barang kirimannya kemudian mengecek alamat pengiriman, menimbang barang kiriman dan menawarkan service pengiriman kepada customer.

3. Customer menentukan service pengiriman yang akan digunakan.

4. Petugas Cash Counter menentukkan ongkos kirim dan input data pengiriman yang akan di cetak dalam bentuk e-connote dan diberikan ke customer lalu customer melakukan pembayaran.

5. Petugas cash counter membuat packing list yang dilaporkan kepada bagian keuangan PT. JNE Cabang Cimone Tangerang.

6. Aplikasi melakukan klasifikasi data service pelanggan menggunakan aplikasi clustering .

7. Bagian keuangan menerima laporan dan mengetahui pola pengelompokkan data service pelanggan tiap tahunnya sehingga dapat menentukkan target untuk tahun tahun berikutnya.

8. Pemilik melakukan pengecekkan laporan.

\subsubsection{Analisa Kebutuhan Sistem}

Seperti pembuatan perangkat lunak pada umumnya, pembuatan aplikasi ini juga memerlukan analisis kebutuhan sistem yang jelas, sehingga mudah dalam perancangan sistemnya. Adapun secara rinci kebutuhan-kebutuhan sistem ini adalah sebagai berikut :

\subsubsection{Analisa Kebutuhan Input}

Data yang digunakan merupakan data service pelanggan PT. JNE Cabang Cimone Tangerang dalam tiga tahun terakhir yaitu dari tahun 2012 hingga tahun 2014. Berikut contoh data service REG (Regular), OKE (Ongkos Kirim Ekonomis) dan YES (Yakin Esok Sampai) tahun 2012: 
Tabel 3.4. Data service YES,REG dan OKE

\begin{tabular}{|c|c|c|c|c|}
\hline & & Reg & Yes & Oke \\
\hline $\mathbf{2 0 1 2}$ & $\mathbf{1}$ & 7788 & 1788 & 2348 \\
\hline & $\mathbf{2}$ & 8541 & 1887 & 2484 \\
\hline & $\mathbf{3}$ & 8885 & 1854 & 3079 \\
\hline & $\mathbf{4}$ & 9093 & 1785 & 3888 \\
\hline & $\mathbf{5}$ & 9763 & 1685 & 4158 \\
\hline & $\mathbf{6}$ & 10400 & 1997 & 4331 \\
\hline & $\mathbf{7}$ & 10502 & 1994 & 5731 \\
\hline & $\mathbf{8}$ & 10487 & 2819 & 4025 \\
\hline & $\mathbf{9}$ & 10593 & 2061 & 4618 \\
\hline & $\mathbf{1 0}$ & 12116 & 2306 & 5461 \\
\hline & $\mathbf{1 1}$ & 11671 & 2543 & 5463 \\
\hline & $\mathbf{1 2}$ & 13010 & 2545 & 6139 \\
\hline & Total & $\mathbf{1 2 2 8 4 9}$ & $\mathbf{2 5 2 6 4}$ & $\mathbf{5 1 7 2 5}$ \\
\hline
\end{tabular}

\begin{tabular}{|c|c|c|c|c|}
\hline & & Reg & Yes & Oke \\
\hline $\mathbf{2 0 1 3}$ & $\mathbf{1}$ & 13610 & 2527 & 6361 \\
\hline & $\mathbf{2}$ & 13244 & 2600 & 6380 \\
\hline & $\mathbf{3}$ & 16046 & 2894 & 7431 \\
\hline & $\mathbf{4}$ & 16661 & 2874 & 6774 \\
\hline & $\mathbf{5}$ & 16258 & 2849 & 4282 \\
\hline & $\mathbf{6}$ & 16699 & 2806 & 3981 \\
\hline & $\mathbf{7}$ & 19275 & 3133 & 4430 \\
\hline & $\mathbf{8}$ & 15102 & 3240 & 2296 \\
\hline & $\mathbf{9}$ & 17884 & 3049 & 3606 \\
\hline & $\mathbf{1 0}$ & 14061 & 2556 & 5363 \\
\hline & $\mathbf{1 1}$ & 24346 & 4266 & 2906 \\
\hline & $\mathbf{1 2}$ & 13490 & 2848 & 4657 \\
\hline & Total & $\mathbf{1 9 6 6 7 6}$ & $\mathbf{3 5 6 4 2}$ & $\mathbf{5 8 4 6 7}$ \\
\hline
\end{tabular}

\begin{tabular}{|c|c|c|c|c|}
\hline & & Reg & Yes & Oke \\
\hline $\mathbf{2 0 1 4}$ & $\mathbf{1}$ & 22506 & 3678 & 3252 \\
\hline & $\mathbf{2}$ & 19911 & 4800 & 2805 \\
\hline & $\mathbf{3}$ & 22400 & 3281 & 3112 \\
\hline & $\mathbf{4}$ & 23255 & 3781 & 3446 \\
\hline & $\mathbf{5}$ & 23898 & 3696 & 3784 \\
\hline & $\mathbf{6}$ & 22590 & 3631 & 3275 \\
\hline & $\mathbf{7}$ & 22984 & 4475 & 2822 \\
\hline & $\mathbf{8}$ & 18356 & 3785 & 2017 \\
\hline & $\mathbf{9}$ & 23509 & 4050 & 2770 \\
\hline & $\mathbf{1 0}$ & 24912 & 4484 & 2433 \\
\hline & $\mathbf{1 1}$ & 23854 & 4262 & 2417 \\
\hline & $\mathbf{1 2}$ & 22060 & 4340 & 2677 \\
\hline & Total & $\mathbf{2 7 0 2 3 5}$ & $\mathbf{4 8 2 6 3}$ & $\mathbf{3 4 8 1 0}$ \\
\hline
\end{tabular}

\subsubsection{Analisa Kebutuhan Proses}

Kebutuhan proses dalam aplikasi ini cenderung menitikberatkan pada penerapan metode $K$ - Means dalam pengolahan data service pengiriman pelanggan tahun 2012, 2013, dan tahun 2014 untuk menghasilkan output yang diharapkan.

\subsubsection{Analisa Kebutuhan Output}

Output yang diharapkan dalam aplikasi ini adalah hasil pengelompokkan data service pelanggan JNE Cabang Cimone Tangerang selama tiga tahun terakhir yang ditunjukkan melalui pola data pada grafik.

\subsection{Perancangan}

3.2.1. Hierarki Menu

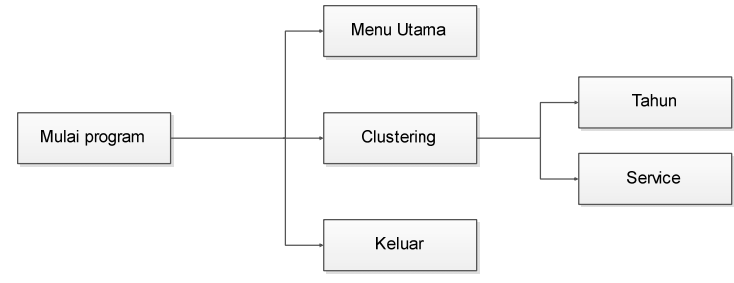

\subsubsection{Flowchart Sistem $K$ - Means}

Berikut merupakan flowchart sistem clustering data service pelanggan tahun 2012, 2013, dan tahun 2014 menggunakan metode K - Means.

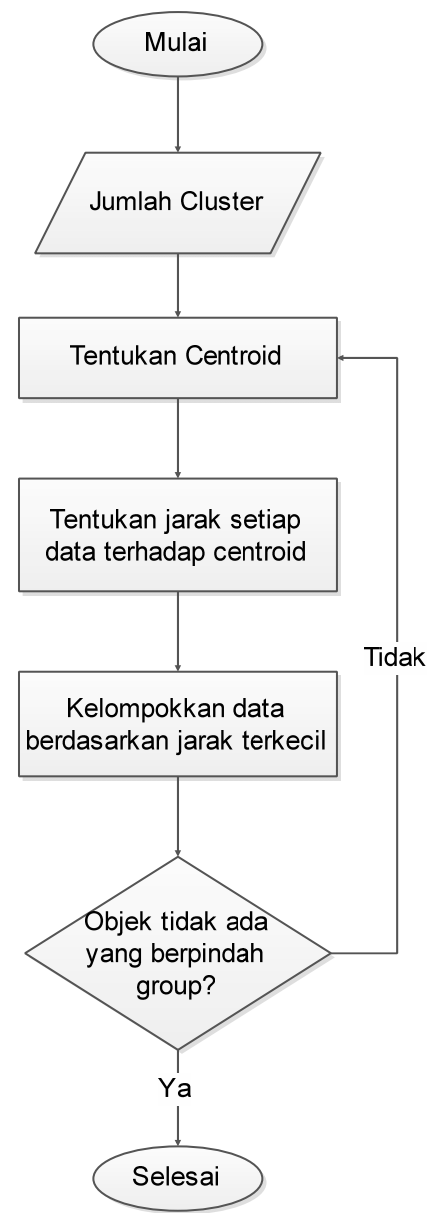

Gambar 3.4. Flowchart Sistem K - Means 


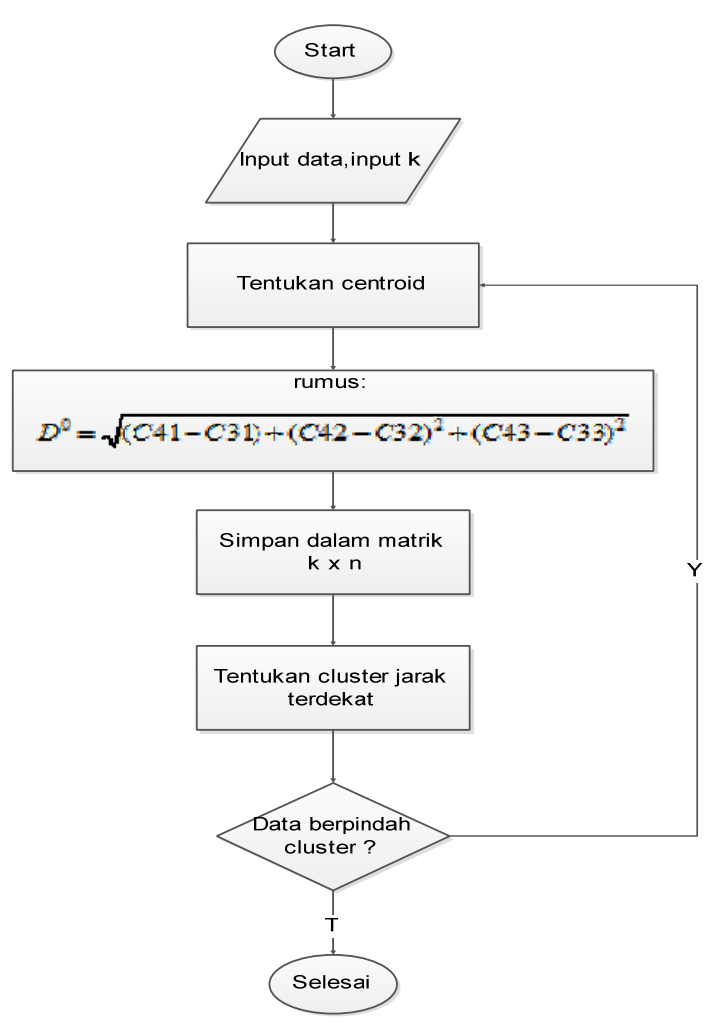

Gambar 3.5. Flowchart Metode K-Means

Berikut merupakan flowchart metode K-Means :

\subsubsection{State Trasition Diagram}

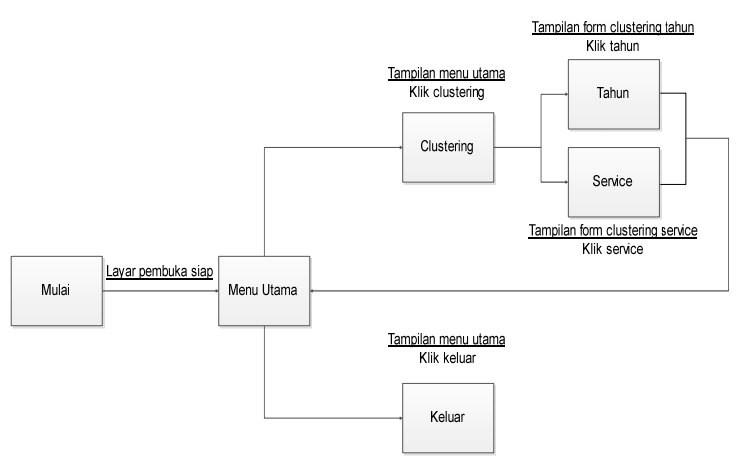

Gambar 3.6. STD Menu Utama

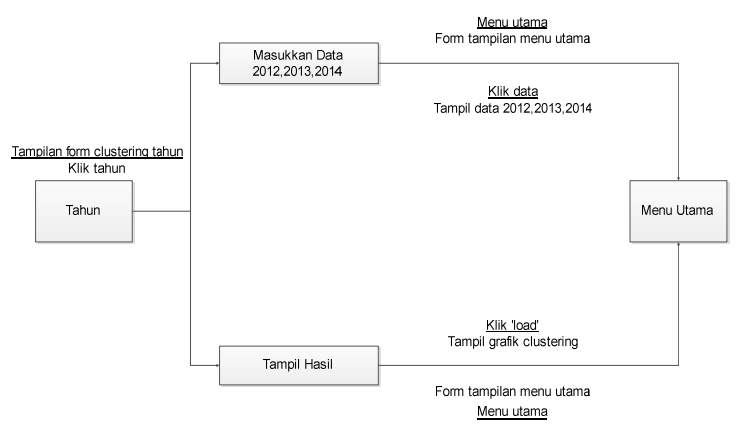

Gambar 3.7. STD Menu Clustering Tahun

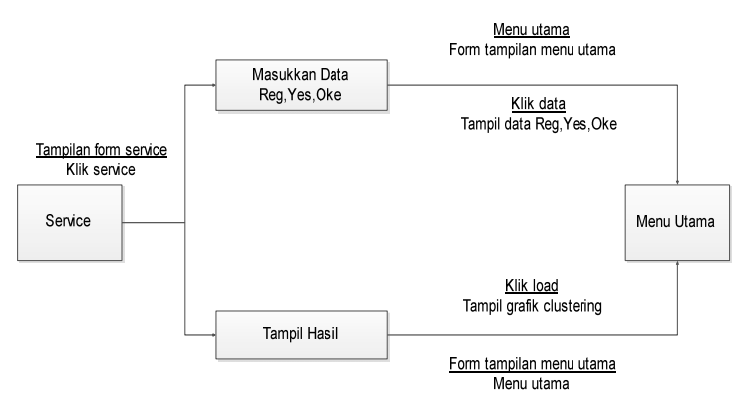

IV. HASIL DAN PEMBAHASAN

A. Form Clustering Tahun

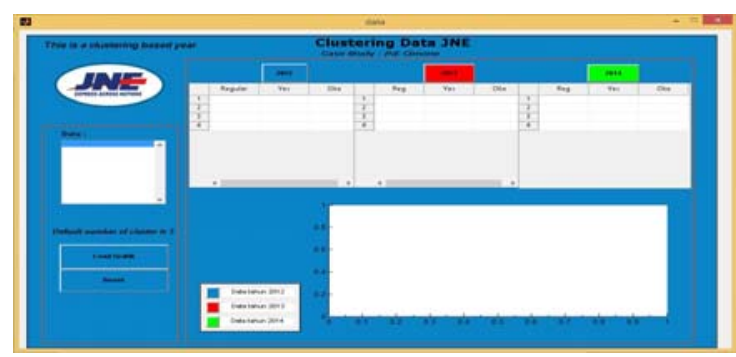

Gambar 4.1. Form Clustering Tahun

Form untuk menampilkan data tahun 2012, tahun 2013 dan tahun 2014. Tombol untuk load grafik dan tombol reset grafik dalam keadaan semula. Terdapat juga satu list box untuk menampilkan daftar data, satu text box untuk input thershold, dua axes untuk menampilkan grafik hasil clustering dan menampilkan logo JNE.

\subsubsection{Insert Data Form Clustering Tahun}

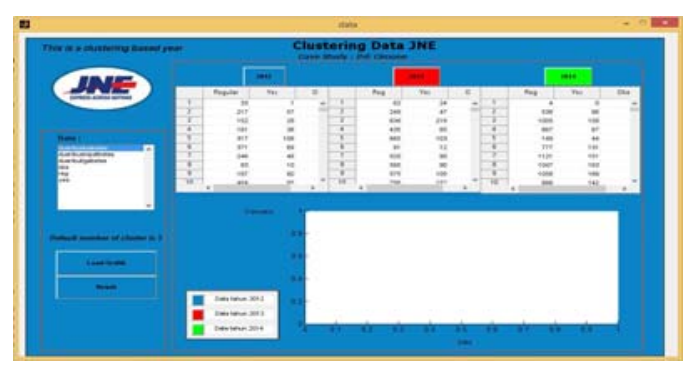

Gambar 4.2. Insert Data Form Clustering Tahun

\subsubsection{Grafik Clustering Tahun}

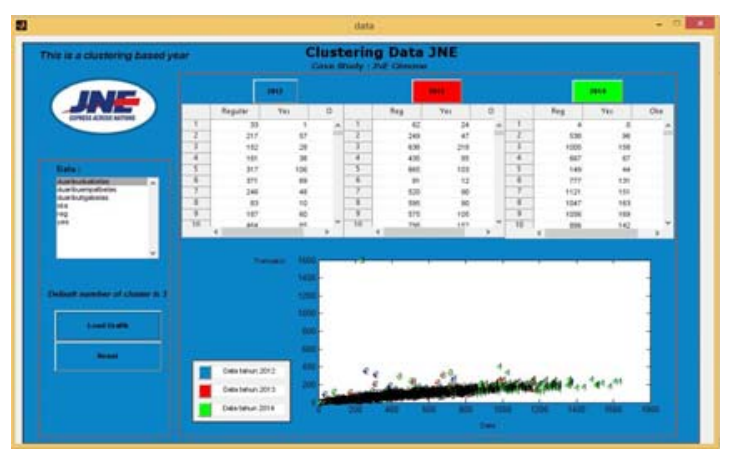

Gambar 4.3. Grafik Clustering Tahun 
Hasil dari grafik di atas menunjukkan bahwa terjadinya pola data yang tidak signifikan dikarenakan banyaknya data dengan jumlah transaksi yang saling mendekati, sehingga terjadi penumpukkan pola data.

\subsubsection{Form Clustering Service}

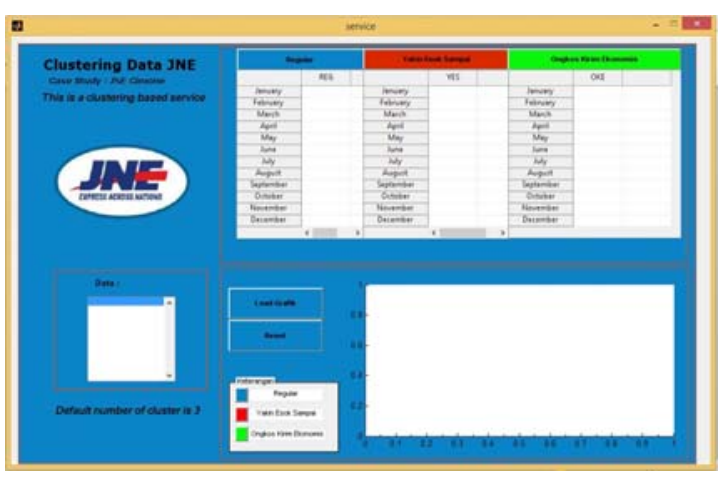

Gambar 4.4. Form Clustering Service

\subsubsection{Insert Data Form Clustering Service}

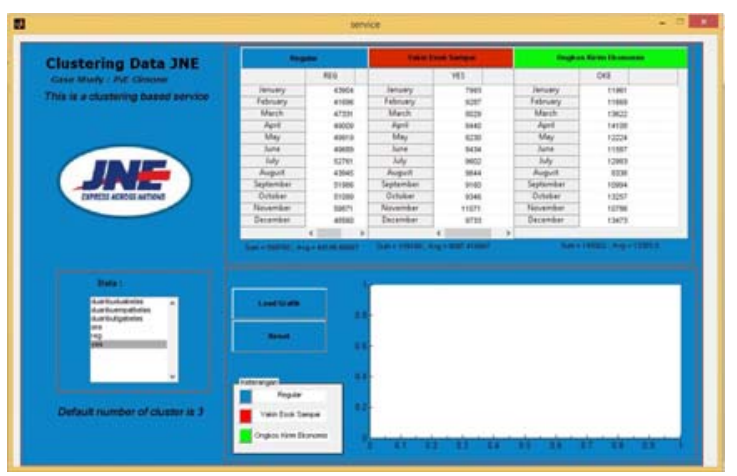

Gambar 4.5. Insert Data Form Clustering Service

\subsubsection{Grafik Clustering Service}

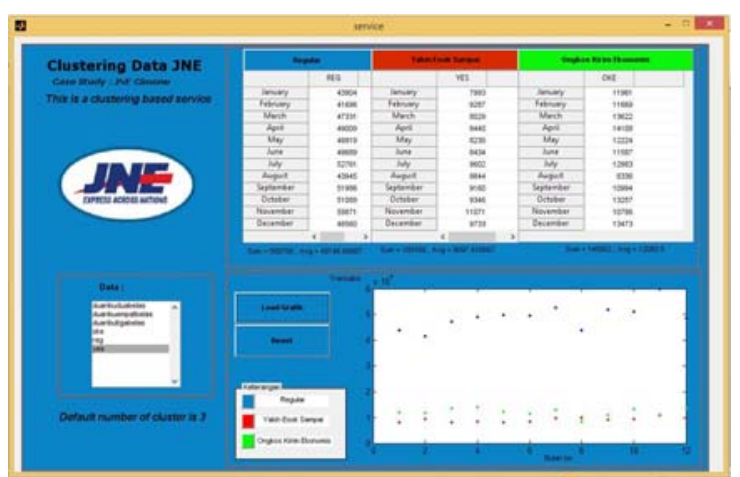

Gambar 4.6. Grafik Clustering Service
Hasil dari grafik di atas menunjukkan bahwa service pengiriman regular paling banyak digunakan

\subsection{Pembahasan}

\section{Aplikasi Clustering Data}

Metode perhitungan ini tidak menggunakan data dengan kuantitatif yang sebenarnya namun memakai data dengan nilai yang sebenarnya dengan jumlah yang sedikit agar memudahkan untuk memahami maksud dari cara kerja algoritma ini. Berikut penjelasannya.

Diketahui data sebagai berikut :

Tabel 4.7. Data percobaan

\begin{tabular}{|l|l|l|l|}
\hline Bulan & Reg & Yes & Oke \\
\hline 1 & 43904 & 7993 & 11961 \\
\hline 2 & 41696 & 9287 & 11669 \\
\hline 3 & 47331 & 8029 & 13622 \\
\hline 4 & 49009 & 8440 & 14108 \\
\hline
\end{tabular}

1. Pengesetan nilai awal titik tengah. Misalkan bulan 1 dan bulan 2 masing-masing menjadi titik tengah (centroid) dari cluster yang akan dibentuk.

2. Tentukan koordinat kedua centroid tersebut, yaitu C1 $=(43904,7993,11961), C 2=(41696$, 9287, 11669) dan C3 $=(47331,8029,13622)$.

3. Menghitung jarak obyek ke centroid dengan menggunakan rumus jarak Euclid. Misalnya jarak bulan $4, C 4=(49009,8440,14108) \mathrm{ke}$ centroid pertama C1 $=(43904,7993,11961)$ adalah $\sqrt{ }(49009-43904)^{2}+(8440-7993)^{2}+$ $\left.(14108-11961)^{2}\right)=5556,12$ jaraknya dengan centroid kedua $\quad \mathrm{C} 2=(41696,9287,11669)$ adalah $\sqrt{ }(49009-41696)^{2}+(8440-9287)^{2}+$ $(14108-11669)^{2}=7755,4$ dan jaraknya dengan centroid ketiga C3 $=(47331,8029$, 13622) adalah $\sqrt{ }(49009-47331)^{2}+(8440-$ $8029)^{2}+(14108-11669)^{2}=2988,87$

4. Hasil perhitungan jarak ini disimpan dalam bentuk matriks $\mathrm{k} \times \mathrm{n}$, dengan $\mathrm{k}$ banyaknya cluster dan $\mathrm{n}$ banyak obyek. Setiap kolom dalam matriks tersebut menunjukkan obyek sedangkan baris pertama menunjukkan jarak ke centroid pertama, baris kedua menunjukkan jarak ke centroid kedua. Matriks jarak setelah iterasi ke-0 adalah sebagai berikut:

$D^{0}=$
$\left\{\begin{array}{llll}43904 & 41696 & 47331 & 5556,12 \\ 7993 & 9287 & 8029 & 7755,4 \\ 11961 & 11669 & 13622 & 2988,87\end{array}\right\}$

5. Clustering obyek : Memasukkan setiap obyek ke dalam cluster (grup) berdasarkan jarak minimumnya. Jadi Bulan 1 dimasukkan ke grup 1, bulan 2 ke grup 2, bulan 3 ke grup 3 . Dan bulan 4 ke grup 1.

6. Ulangi langkah diatas sampai hasil menunjukkan bahwa tidak ada lagi obyek yang berpindah grup, dan algoritma telah stabil. 


\subsubsection{Data mining}

Proses data mining pada aplikasi ini meliputi :

1. Seleksi Data (Data Selection), Tahap seleksi data pada penelitian ini yaitu seleksi data service pengiriman REG (Regular), YES (Yakin Esok Sampai) dan OKE (Ongkos Kirim Ekonomis) selama tiga tahun dari tahun 2012 hingga 2014.

2. Pembersihan Data (Data Preprocessing) Tahap pembersihan data pada penelitian ini dilakukannya penghapusan data yang tidak terpakai.

3. Transformasi Data (Data Transformation), Tahap transformasi data pada penelitian ini yaitu pemberian coding menggunakan data yang sudah di klasifikasi sehingga membentuk pola yang dicari.

4. Data mining, Tahap data mining merupakan proses pencarian pola menggunakan metode tertentu. Pada penelitian ini menggunakan metode $K$ - Means.

5. Evaluasi Pola (Interpretation/Evalution), Tahap evaluasi pola pada penelitian ini yaitu pola data ditampilkan pada grafik dan dilakukan pemeriksaan yang menghasilkan bahwa REG merupakan service pengiriman tertinggi.

\section{PENUTUP}

\subsection{Simpulan}

Kesimpulan yang didapat penulis sebagai berikut :

1. Hasil pengolahan data dengan menggunakan aplikasi ini adalah jenis service REG (Regular) yang menempati urutan pertama , sehingga dapat disimpulkan bahwa pelanggan lebih memilih jenis service REG (Regular) dikarenakan jenis pelayanan ini menawarkan layanan pengantaran cepat, aman dan handal sampai ke pelosok Indonesia.

2. Jenis Service yang menempati urutan kedua berdasarkan aplikasi adalah jenis service OKE (Ongkos Kirim Ekonomis) merupakan layanan dengan harga ekonomis in memanfaatkan moda transportasi cargo udara dan angkutan darat, menghubungkan kota-kota besar, ibu kota provinsi sampai ke kabupaten.

3. Jenis Service yang menempati urutan ketiga adalah Service YES mengantisipasi kebutuhan dengan target pengantaran $\mathrm{d} i$ tujuan pada keesokan harinya dengan menawarkan layanan premium pengantaran dalam waktu satu hari. Sebagai bentuk tanggung jawab atas kualitas layanan ini, JNE memberikan jaminan uang kembali (biaya kirim) apabila kiriman tidak terantar pada keesokan harinya.

4. Aplikasi hanya dapat mengolah tipe data numerik untuk menentukan pengelompokkan data berdasarkan tahun dan service pengiriman, serta dapat menampilkan pola data service selama tiga tahun berdasarkan cluster 1, cluster 2 dan cluster 3.

\section{REFERENSI}

Agusta, Y., (2007), K-Means - Penerapan, Permasalahan dan Metode Terkait, Jurnal sistem dan Informatika 3: 47-60.

Away, G. A. (2014). The Shortcut of Matlab Programming. Bandung: Informatika.

Eko Prasetyo. (2013). Data Mining Konsep dan Aplikasi Menggunakan Matlab. Andi publisher.

Junjie wu. (2012). Advances in K-Means Clustering

Kusrini \& Emha Taufiq Luthfi. (2009). Algoritma Data Mining. Andi publisher.

Sianipar, R. (2013). Pemrograman Matlab Dalam Contoh dan Terapan. Bandung: Informatika.

Supranto. 2006. Pengukuran Tingkat Kepuasan Pelanggan. Cetakan Ketiga. Rineka Cipta: Jakarta 